Andrej Žmegač

Institut za povijest umjetnosti, Zagreb

\title{
»Isječak kružnog vijenca s izbočenjem prema jugu«: Zemljakova škola Rapska
}

\author{
Izvorni znanstveni rad - Original scientific paper \\ Primljen - Received 28. 9. 2020. \\ UDK 72Zemljak, I. \\ 727:373.3](497.5Zagreb)
}

DOI doi.org/10.31664/ripu.2020.44/2.13

\begin{abstract}
Sažetak
U radu je riječ o razmjerno slabo poznatoj školi arhitekta Zemljaka iz 1938. godine. Primarno se govori o projektu jer zgrada nije izvedena cjelovito, a recentno je doživjela i različite preinake. Izvorna zamisao vidi se $u$ idejnom projektu, gdje se ističe različit tretman tamnijega učioničkog trakta i bijelo ožbukanoga poprečnog sklopa. Navodi se kako je ova školska zgrada zaobljenom formom u velikome mjerilu glavnoga trakta iznimka u njegovu stvaralaštvu. U prostornoj analizi autor se medu
\end{abstract}

ostalime bavi smještajem stubišta koje ima neuobičajen položaj u odnosu na predvorje, ali logično tvori dio učioničkog trakta, povezujući tri etaže. $U$ radu se skreće $i$ pozornost na funkcije koje je škola u ono doba trebala zadovoljiti, a koje su je činile de facto socijalnom ustanovom (kuhinja, kupaonica, liječnik). Takoder je istaknuta činjenica da je $u$ zgradi škole bilo projektirano $i$ dječje sklonište (obdanište), $i$ to $u$ prizemlju glavnog trakta.

Ključne riječi: moderna arhitektura, osnovna škola, periferija, Ivan Zemljak, Zagreb

»Zgrada škole u Rapskoj ulici 3 građena je za radničku četvrt, funkcionalnog je tlocrta, originalnog prostornog i suvremenog konstruktivnog rješenja, te vrijedan primjer moderne međuratne arhitekture - fragment je iz obrazloženja upisa te zgrade u Registar kulturnih dobara RH. U opusu Ivana Zemljaka, znamenitog arhitekta školskih zgrada, ${ }^{1}$ ova je škola redovito dobivala manje pozornosti od drugih njegovih ostvarenja iz tridesetih godina 20 . stoljeća. ${ }^{2}$ To je zato što ona nije tako dramatična ${ }^{3}$ kao škola na Jordanovcu, niti tako raskošna ${ }^{4}$ kao škola u Selskoj. Stoga je bila malo analizirana, te neke njezine specifične vrijednosti nisu niti mogle biti uočene. Međutim, imamo li na umu cijeli Zemljakov opus, moglo bi se kazati da i njegove poznatije školske zgrade traže iscrpniju analizu. Također, može se zapaziti da u evaluaciji njegovih djela postoje katkad velike amplitude, što možda svjedoči o izostalim analizama ili pak neujednačenim kriterijima. Navedimo primjer Zemljakove škole na križanju Savske i Ulice grada Vukovara koju Zdenko Kolacio i Ivo Maroević smatraju ponajboljim njegovim ostvarenjem, ${ }^{5}$ dok je Aleksander Laslo tek spominje, ne naglašavajući je opisom i grafičkim prilozima kao većinu ostalih; ${ }^{6}$ tako se može zaključiti da je nije smatrao posebno važnim djelom.

\section{Potreba za gradnjom novih škola}

Kao što je poznato, Zemljak se, kao zaposlenik Gradskog poglavarstva, suočavao s problemom nedostatnog broja školskih zgrada u Zagrebu; grad je između dvaju ratova brzo rastao doseljavanjem i prirastom radničkoga stanovništva na periferiji. U tekstu Uz nove zagrebačke škole iz 1933. godine Zemljak navodi kako su tri njegove netom podignute škole (Jordanovac, Selska, Jakićeva) tek poboljšale problem učioničkog prostora, ali da Zagrebu nedostaje još uvijek 89 učionica! A i te učionice primale su u ono doba previše djece: ne bi smjele primati više od pedeset đaka, kaže arhitekt, no iz njegovih se navoda dade zaključiti da ih je znalo biti i šezdesetak. ${ }^{?}$

Osim samog povećavanja kapaciteta školskog prostora, Zemljak je bio vrlo svjestan da nove škole moraju djeci boravak ondje činiti što ugodnijim, što je prije svega značilo u svijetlim i dobro zračenim prostorima. Spomenuti tekst svjedoči o njegovoj zauzetosti za dobrobit djece, i to posebno siromašne i boležljive djece na zagrebačkoj periferiji. U suglasju s njime pisao je u istome časopisu i Lujo Thaller, liječnik i gradski 

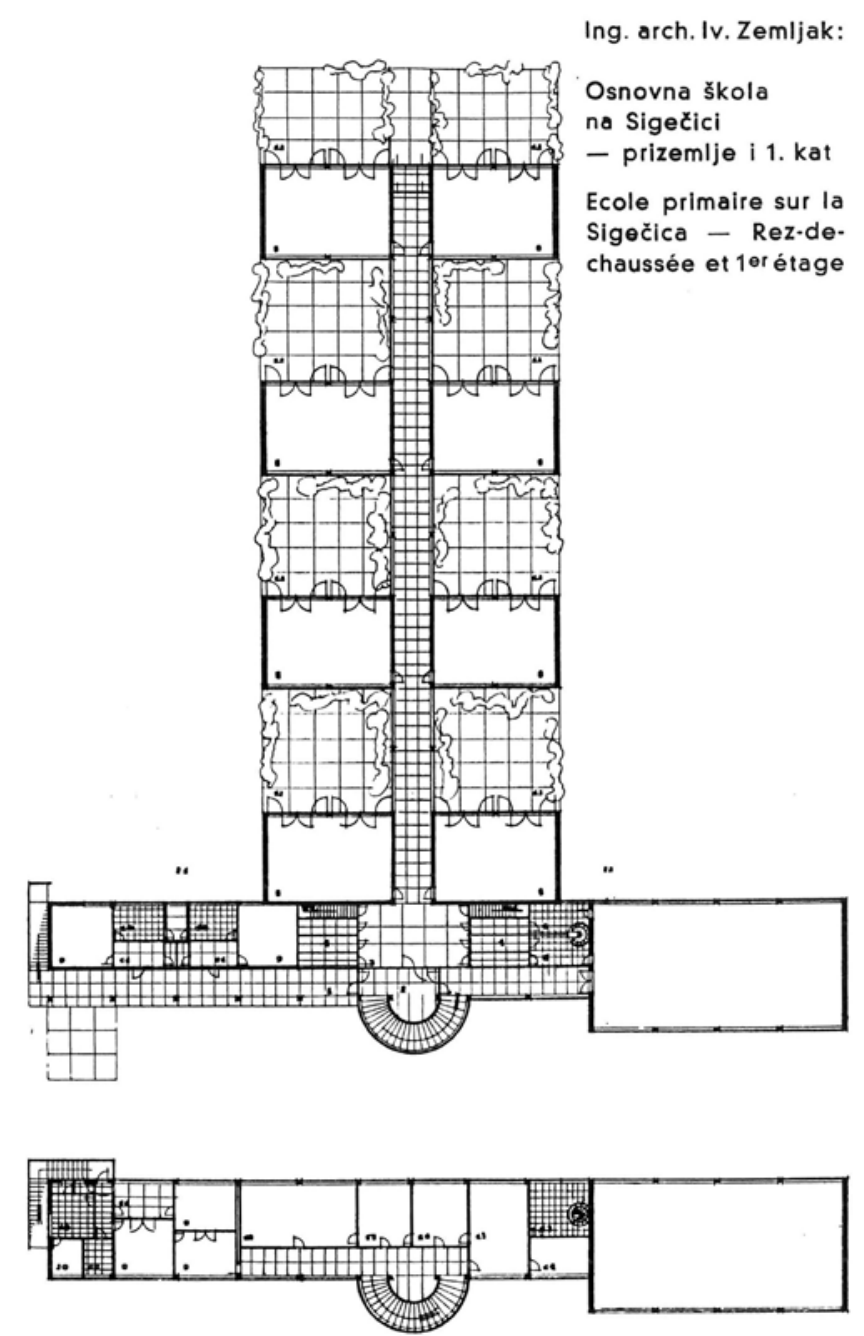

1. Ivan Zemljak, prvi projekt za školu na Sigečici (Arhitektura, 12, 1933.)

Ivan Zemljak, the first project for a school in Sigečica

zastupnik, podsjećajući da su stare škole uobičajeno bile mračne i da su zaudarale, što se moralo mijenjati. Zemljak i Thaller razumijevali su važnost prostora za progresivnu pedagogiju prije no što su to prepoznali pedagozi, koji su u ono doba izgleda više marili za kurikul nego za prostore u kojima đaci prate nastavu. ${ }^{8}$

Između dvaju svjetskih ratova gradske su vlasti nastojale rješavati i problem dnevnog smještaja radničke djece, čiji bi roditelji nerijetko radili od jutra do mraka. $\mathrm{U}$ tu su svrhu uređivana tzv. skloništa (ili obdaništa), sa zadaćom da zbrinu predškolsku djecu, ali i školsku djecu po završetku nastave. Zbog tog nadopunjavanja funkcija škole i dječjeg skloništa redovito su podizani u neposrednom susjedstvu ili bi čak bili smješteni u istoj zgradi. Skloništa su bila prave socijalne ustanove jer su siromašnoj djeci trebala osigurati ono što im oskudni roditeljski dom nije mogao pružiti. ${ }^{9}$ Od 1930. godine i donošenja Zakona o zdravstvenoj zaštiti učenika ${ }^{10}$ škole de facto postaju i socijalne ustanove jer đacima osiguravaju prehranu, potrebnu higijenu (kupaonica, tuševi) te liječnika koji je trebao nadzirati njihovo zdravlje i razvoj. Ili, riječima samog
Zemljaka, »škola iz dana u dan produbljuje i koncentrira u sebi sav socijalni rad oko siromašne djece, preuzimajući njihovu ishranu, podržavajući skloništa, savjetovališta matera, dječje ambulante, dječji šport i zabavu«. ${ }^{11}$

$\mathrm{U}$ doba intenzivne izgradnje škola u Zagrebu bilo je zamišljeno da pučku školu dobije i naselje Sigečica, smješteno istočno od Držićeve ulice i južno od današnje Ulice grada Vukovara. Taj predio bio je prava zagrebačka periferija, u ono doba još s kukuruzištima i pašnjacima, do kojih su dopirale savske poplave; izvornu izgradnju tvorili su kućerci i skromne radničke nastambe. Intenzivnija urbanizacija započinje potkraj dvadesetih godina planskim podizanjem sklopa obiteljskih kuća. U to doba pristupa se i regulaciji uličnih poteza, a Sigečica i službeno postaje naseljem, tj. dijelom grada. ${ }^{12}$ Zemljak, uz prezentaciju svojih netom izgrađenih škola, početkom tridesetih donosi i projekt za školu na Sigečici, s kratkim komentarom. Kako se može vidjeti, škola je imala biti pretežito simetričnog rasporeda (otklon čini dvorana za tjelovježbu) i zasigurno u duhu njegove tadašnje bliskosti neoplasticizmu. Prema ulici (Ulici grada Vukovara, tj. tadašnjoj Dubrovačkoj?) trebao je stajati servisni i upravni jednokatni trakt, a prema jugu u osi protezati se trijem $s$ obostrano smještenim samostalnim učionicama, $u$ smislu zasebnih volumena, svaka sa svojom terasom za poduku na otvorenom. Da je škola tada i izgrađena, bila bi to prva njegova škola s učionicama kao pojedinačnim volumenima, koncepcije koju je nešto kasnije izvodio s varijantama u svojim skloništima (Jordanovac, Laščinska, Knežija) te školi na Kozjaku. ${ }^{13}$ No nekoliko godina koje će proteći do ostvarenja škole u Rapskoj, donijet će posve novo projektno rješenje. ${ }^{14}$

\section{Projekt nove škole na Sigečici}

Dokumenti povezani s novom koncepcijom te škole potječu najkasnije iz 1938. godine. U prilogu građevinskoj dozvoli iz iste godine vidi se situacija nove škole: smještena je u neizgrađeni i urbanistički neregulirani prostor južno od Dubrovačke, a sjeverno od Rapske ulice, jugoistočno od novoizgrađene crkve Svete Obitelji. ${ }^{15}$ Novu školsku građevinu karakterizira glavni trakt te $s$ istočne strane manji poprečni trakt. Glavnom traktu je pročelje izbočeno, pa ga stoga možemo nazvati i konveksnim; Maroević ga je točno opisao kao »isječak kružnog vijenca s izbočenjem prema jugu « ${ }^{16} \mathrm{a} \mathrm{mi}$ ćemo ga radi jednostavnosti zvati glavnim ili konveksnim. Poprečna os toga tijela postavljena je u pravac sjever-jug, a radijus zakrivljenosti iznosi 90 metara. $\mathrm{Na}$ situacijskom planu vidi se kako je istočno uza zgradu škole trasirana ulica (Nova ulica) koja povezuje Rapsku s Dubrovačkom, današnja Olipska. I premda se u zgradu ulazi iz te ulice, škola je do danas zadržala adresu Rapska 3.

Arhitekt je školsku zgradu koncipirao tako što je glavni trakt namijenio učionicama (u idejnom projektu 12, u realizaciji 10), dok poprečni trakt sadržava dvoranu, ulazni sklop, kuhinju, kupaonicu, kotlovnicu i slične prostorije, na katu zbornicu i direktorovu sobu. Rastvaranje prizemlja trijemom, čest i omiljen postupak moderne arhitekture, javlja 


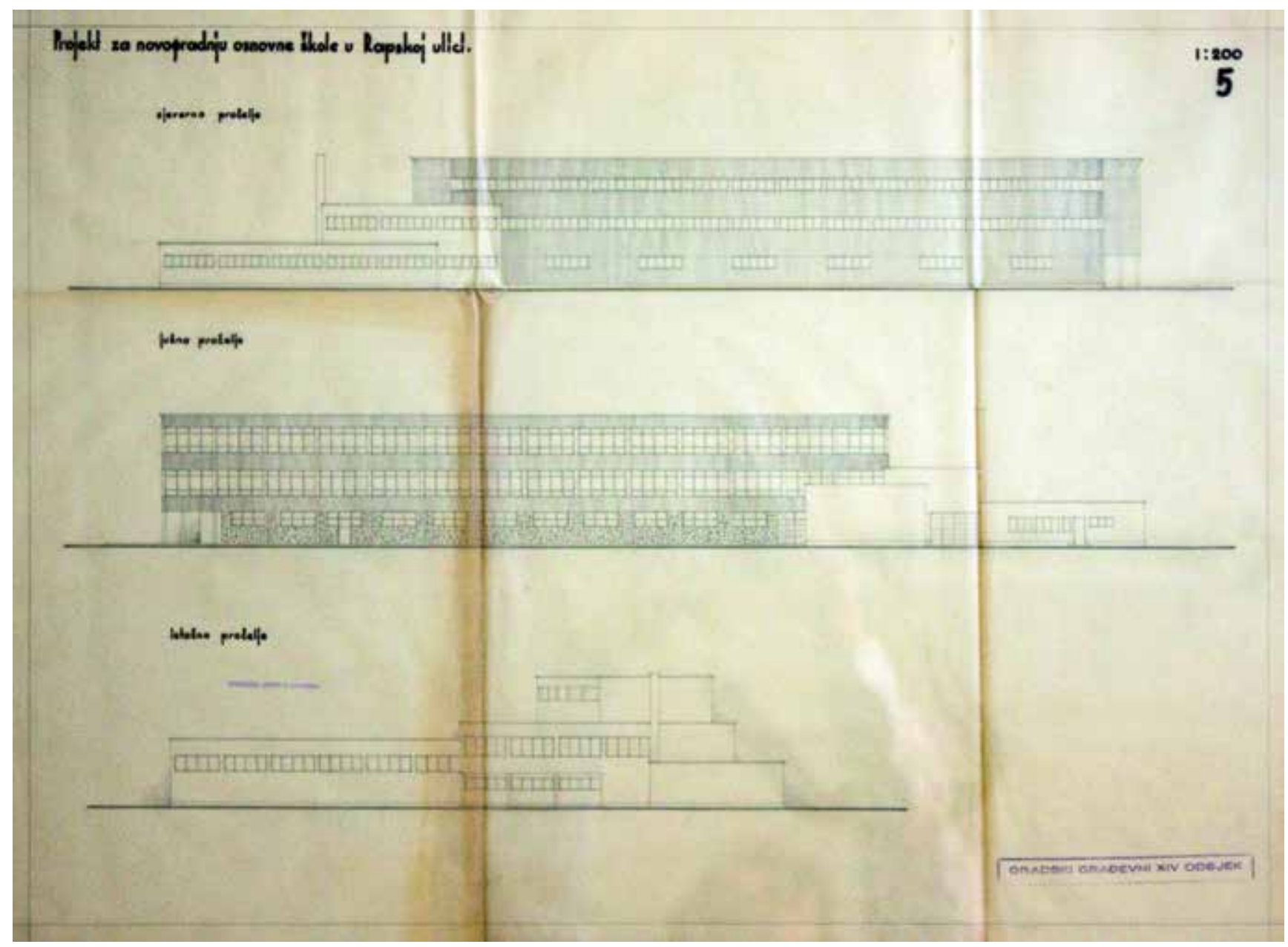

2. Ivan Zemljak, idejni projekt, 1938. (Državni arhiv u Zagrebu)

Ivan Zemljak, preliminary design, 1938

se pred glavnim ulazom $\mathrm{u}$ »servisnom « traktu, kao i cijelom duljinom glavnog trakta. Ovdje prizemlje sadržava dječje sklonište (obdanište), a trijem pruža mogućnost zaštićenog boravka na otvorenom.

Najizvorniju Zemljakovu zamisao za školu te koncepcije pokazuje idejni Projekt za novogradnju osnovne škole u Rapskoj ulici $(1: 200)$, možda i raniji od 1938 . godine. ${ }^{17} \mathrm{Tu}$ se vide neka od bitnih obilježja Zemljakova rješenja: glavni dvokatni trakt oblikovan je kao jednostavno i kompaktno tijelo, a njemu se s istoka pridružuju »razigrani« prateći volumeni. Kompozicija se uspjelom doima osobito pogledom sa sjevera, gdje se ističe zanimljiva gradacija masa od prizemne do dvokatne. $S$ juga i istoka na nacrtima se uočava pak dugo tijelo dvorane za tjelovježbu i priredbe, koja je ostala neizgrađena; treba naglasiti na ovome mjestu da ćemo se primarno baviti Zemljakovim projektom, to znači njegovom izvornom i cjelovitom zamisli. Dakle, već pri izgradnji nije izveden cijeli projekt, a povrh toga u kasnijem razdoblju, sve do danas, zgrada je bila na razne načine preuređivana i dograđivana, što je, uostalom, nemila sudbina i nekih drugih Zemljakovih škola. ${ }^{18}$

Valja uočiti da zapadni završetak glavnog trakta stoji na stupovima, pa je niz stupova u prizemlju vođen dakle i oko zgrade. I naposljetku, vrlo je važno i vrlo uočljivo da Zemljak u obradi pročelja različito tretira glavni trakt i sklop volumena na istočnoj strani: dvokatni učionički trakt sive je boje, što je postignuto oblogom valovitog salonita te rustikom lomljenog kamena u prizemlju glavnog pročelja. $S$ druge strane, manji servisni volumeni uobičajeno su završeni bijelom žbukom. ${ }^{19}$

Sljedeća faza projekta, koja se u detaljima razlikuje od opisanog prikaza, vidljiva je iz priloga građevinskoj dozvoli; ti Zemljakovi nacrti nose datum 16. 4. 1938. Prethodno odobrenje izdalo je Tehničko odeljenje kr. Banske uprave Savske banovine 14. 6., a građevinsku dozvolu izdalo je Gradsko poglavarstvo 10. 8. $1938 .{ }^{20}$ Škola je onda izgrađena 1938./1939. godine.

Glavni je trakt sada na zapadnoj strani završen jednostavno, bez bočnih stupova u prizemlju. Također, nešto je skraćen, jer dok je na ranijem nacrtu u svakom katu imao 14 prozorskih grupa, sada ih ima po 12; to je značilo da je trakt skraćen za jednu učionicu po katu. ${ }^{21}$ Promjena je potom uočljiva na južnom pročelju dvorane, koje je ranije bilo lišeno bilo kakvih otvora, a sada se ovdje pojavljuje ulaz te prozori. Važno je upozoriti i na sljedeću pojedinost: prethodni je nacrt zgradu prikazao na jedinstvenoj razini tla, no uistinu se ona nalazi 


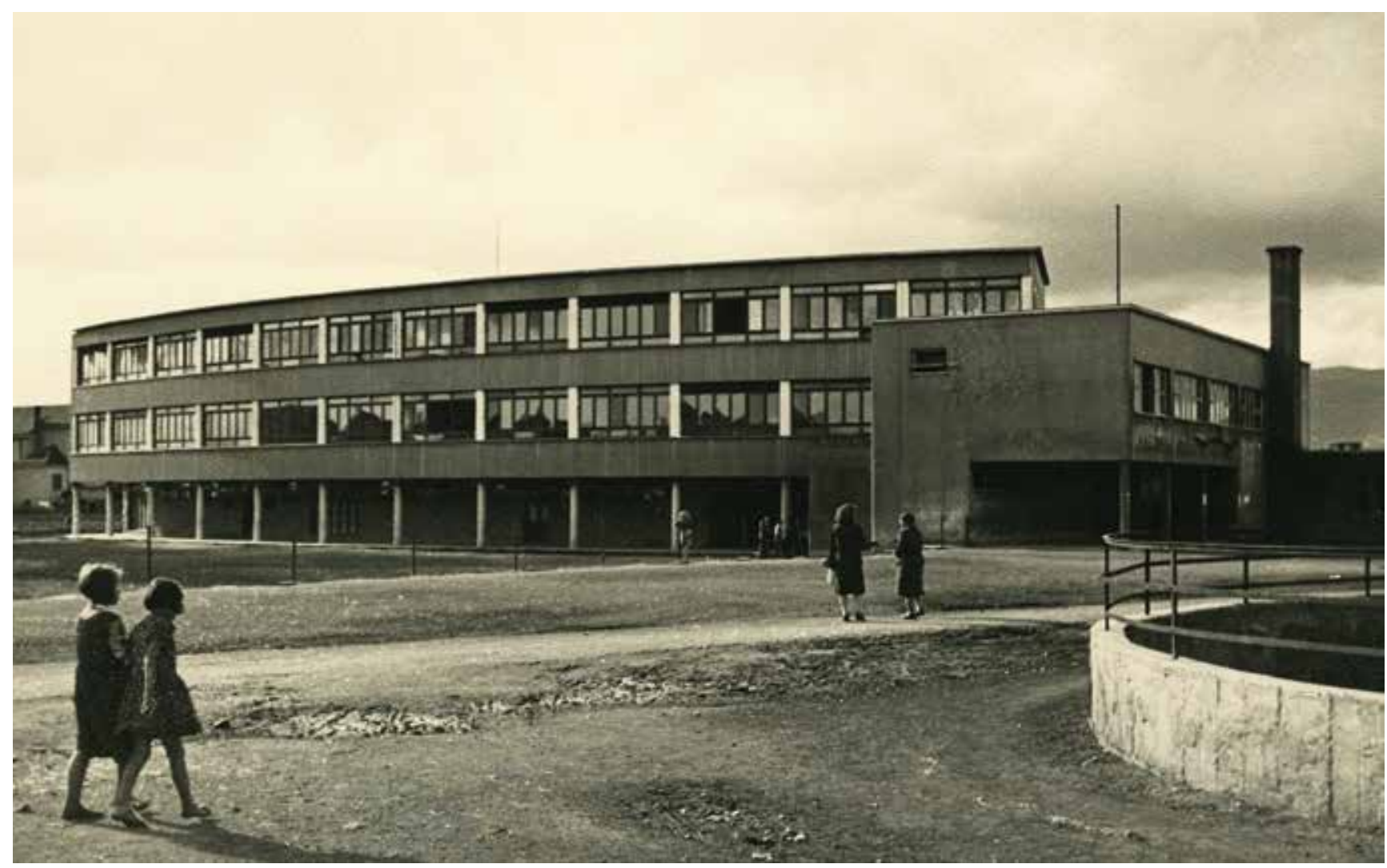

3. Škola Rapska, oko 1945. - 1950. (Muzej grada Zagreba, MGZ-fot-16994)

Rapska School, around 1945-1950

na različitim razinama. Glavni dvokatni trakt stoji naime $\mathrm{u}$ depresiji, na nižem terenu, te je razina njegova prizemlja oko metar niža od glavnog ulaza u školu na istočnoj strani. U pomnijem i detaljnijem (1:100) projektu uz građevinsku dozvolu ta razlika je i naznačena.

U katove glavnog trakta Zemljak je smjestio po pet učionica, pa je to sada školska zgrada s deset učionica. ${ }^{22}$ One su, dakako, uz glavno, južno pročelje, opremljene uobičajenim visokim trodijelnim prozorima. Taj tip prozora, s gornjim i donjim dijelom koji se otvaraju oko horizontalne osi te srednjim što se otvara oko vertikalnih osi, bio je, prema Zemljakovim riječima, provjeren i posve je zadovoljavao u onim rješenjima gdje se učionica morala prozračivati samo $s$ jedne strane. ${ }^{23}$ Duž učionica proteže se hodnik u kojemu je $\mathrm{zid}^{24}$ iskoristio za zidne ormare za izlaganje učeničkih radova, pojedinost koju rado spominje pišući o svojim školama. Zadaća je arhitekta očito bila u zgradu škole integrirati i dječje sklonište (obdanište), jer takvu namjenu prostorija nalazimo upisanu u prizemlju glavnog trakta. To je imala biti zasebna i samodostatna cjelina, sudeći po tome što je imala primjerice vlastitu kuhinju, jednako kao i škola. Tu je u prizemlju bila predviđena i soba za liječnika, no komunikacijski povezana sa školom, ne s dječjim skloništem.

Kako je prije rečeno, neizgrađena dvorana trebala se nadovezivati prema jugu, te kao dio istočnoga sklopa tvoriti određenu protutežu glavnom traktu. Dvorana uobičajenog tipa bila bi namijenjena tjelovježbi i priredbama ${ }^{25}$ jer je na jednoj užoj strani bila predviđena pozornica i prostor za orkestar. Imala je i vanjske ulaze, te je zato, izgleda, trebala služiti i lokalnom stanovništvu koje u nju ne bi ulazilo iz školske zgrade. Zlokobno zvuči ono što je također bilo zadano programom: uz građevinsku dozvolu priložen je i projekt za sklonište od zračnog napada, koje je bilo predviđeno podno dvorane, u prostoru oko udubljenog orkestra. Trebalo je biti prostrano, imati pričuvni izlaz/ulaz te biti opremljeno filtrom, ventilatorom i pumpom. Sama dvorana nije doživjela izvedbu, ${ }^{26}$ ali je bio izgrađen spojni trakt prema njoj, u kojemu se, primjerice, nalazila i kupaonica. ${ }^{27}$

Navedimo na ovome mjestu zanimljiv Zemljakov tehnički opis zgrade. Sam dokument nije datiran, ali je nastao u trenutku kada je već bilo odlučeno da će zgrada imati 10 umjesto 12 učionica, te da se dvorana u prvoj fazi neće graditi: "Škola je osnovana djelomično dvospratna sa prizemljem i bez podruma, a djelomično prizemno odnosno jednospratno. Škola se sastoji od 10 učionica te 2 dvorane, skloništa za djecu u prizemlju sa potrebnim školskim nuzprostorijama. U prizemlju se nalaze garderobe za učenike, stan ložača i pazikuće, centralno loženje, ordinacija liječnika, te gombaonička dvorana sa garderobama i tuševima. Ispod ove dvorane koja će se graditi u drugoj etapi nalazit će se sklonište protiv napadaja iz zraka. U I katu nalaze se dvije kancelarijske sobe i zbornica sa klozetima te 5 učionica i kabinet. U II katu nalazi se 5 učionica sa jednim kabinetom i klozetima. Krov je ravan pokriven sa bitumen-jutom. Konstrukcija je 
armirano betonski skelet između kojega su zidovi od opeke $12 \mathrm{~cm}$ sa zračnim prostorom. Stropovi su armirano betonske rebričaste ploče računate za korisno opterećenje $300 \mathrm{~kg} / \mathrm{m}^{2}$ u razredima i kancelarijama i $400 \mathrm{~kg} / \mathrm{m}^{2} \mathrm{u}$ komunikacionim prostorima. Temelji su pojedinačni ispod pojedinih stupova. Pročelje dvokatnog dijela obloženo je valovitim salonitom, a ostali dijelovi zgrade ožbukani. Grijanje je centralno sa toplom vodom . $^{28}$

Jedino stubište koje povezuje katove zgrade nalazi se usred građevine, na spoju glavnog trakta s poprečnim sklopom. U dosadašnjoj literaturi ono je bilo, moglo bi se reći, glavni predmet kritike ove Zemljakove školske zgrade. Maroević je prvi ocijenio da se »stubište nije najsretnije smjestilo «, ${ }^{29}$ a na tom su tragu pisali i kasniji autori. Bilo je, dakako, uočeno da stubište funkcionira kao dio učioničkog trakta te mu je stoga kompozicijski i prilagođeno; to znači da je zbog konveksnog rasporeda tog trakta stubište smješteno ukošeno u tlocrtno pravokutno predvorje, što nema toliko funkcionalne posljedice, koliko se doima iznenađujuće i nezgrapno u pogledu na tlocrt zgrade. No bilo je to praktično jedino rješenje kad je već odabran kružni isječak za tlocrtnu osnovu glavnog trakta. Naime, stubište je prvenstveno u funkciji glavnog trakta te ono vodi do njegova drugog kata, što je za etažu više od ostatka školske zgrade; zbog toga je jasno da je moralo biti logično smješteno u njegov korpus. Eventualno zakretanje stubišnog tijela kako bi u prizemlju bilo postavljeno ortogonalno prema predvorju, tražilo bi i neke »slijepe« prostore prema volumenu glavnog trakta ili pak trapezno deformiranje susjednih prostora. Svakako se stubišnim tijelom nije mogao postići ortogonalan postav i prema glavnom i prema poprečnom traktu, pa je logično da bude prilagođeno višem traktu, gdje povezuje njegove tri etaže.

Sve proizlazi, dakako, iz autorove odluke da kombinira prizmatičan i konveksni trakt te da ih razmjesti tako da su njihove osi postavljene pravilno prema stranama svijeta, tj. u smjeru sjever-jug. Na taj je način postigao specifičan dinamizam između tih dvaju volumena. Stubišno tijelo kao dio konveksnog trakta moglo je stajati i ortogonalno prema predvorju, u slučaju da se učionički trakt nadovezivao na prizmatični trakt pod pravim kutom, ali bi to značilo i drukčiji kompozicijski odnos dvaju volumena; njihove osi više ne bi bile usporedne kao u prethodnom slučaju, $t j$. $u$ Zemljakovu projektu, i njihova veza bila bi konvencionalnija, a dinamika oslabljena.

Naveli smo da nema većih funkcionalnih posljedica Zemljakova rješenja, no činjenica je da po ulasku u predvorje isprva nije očito kamo valja krenuti, jer stubište nije vidljivo. Ono se, naime, nalazi iza zida, još i zaokrenuto zbog svoje pripadnosti drugome, konveksnom traktu. Na ovome mjestu mogli bismo podsjetiti na Maroevićevu kritiku pojedinih Zemljakovih škola, jer bi se ona donekle mogla protegnuti i na opisanu situaciju u Rapskoj. Po njegovu shvaćanju riječ je $\mathrm{o}$ "nedefiniranosti koju on vidi upravo u ulaznim zonama školskih zgrada. ${ }^{30}$ Smještaj stubišnog tijela u Rapskoj očit je kompromis, čega je zasigurno bio svjestan i arhitekt, no on je diktiran višom idejom o posve određenom rasporedu volumena nove zgrade.

\section{Zaobljena forma u hrvatskoj modernoj arhitekturi}

Kontekstualiziramo li zaobljenu formu glavnog trakta, može se uočiti da je takva forma općenito u hrvatskoj modernoj arhitekturi - možda paradoksalno - vrlo prisutna. Naime, u doba naglašavanja »čistih « volumena, razumljivo je da se uz uobičajena prizmatična tijela (kvadre) javljaju i cilindrična tijela, i to ne samo kao afirmacija tog oblika, nego i zbog stupanja u dijalog s osnovnim prizmatičnim volumenom, radi dinamizacije kompozicije. Spomenimo da se zaobljena forma pojavljuje već kao zaobljenost uglova, i to u različitim radijusima (Steinmannova škola u Križanićevoj, 1930.), ali i kao zaobljeni završetak osnovnoga prizmatičnog tijela (škola istog arhitekta u Kušlanovoj, 1934., te brojne druge zgrade). U takvim, najčešćim rješenjima zaobljenost nema utilitarnu svrhu, nego se javlja upravo radi dinamizacije kompozicije, eventualno kao odjek art décoa. Utilitarnu genezu jedino imaju (polu)cilindrični volumeni stubišnih tijela. Kao puno cilindrično tijelo spominjemo zatim aneks paviljona u Weissmannovu projektu za Zakladnu bolnicu na Šalati (1930.). U malobrojnim, ali vrlo poznatim slučajevima cilindričan volumen postao je i rješenjem osnovnog korpusa građevine, kao što je to Planićeva vila na Prekrižju ili Meštrovićev Dom likovnih umjetnosti.

Međutim, valja spomenuti i brojne situacije u kojima su zaobljeni volumeni stvoreni zbog oblika parcele, odnosno toka ulice kao ograničenja. Jedan je od takvih primjera uzak kut pod kojim se spajaju ulice, pa su takvu nepovoljnu situaciju arhitekti rado rješavali projektiranjem zaobljenoga, i to konveksnog tijela (Drago Ibler, Upravna zgrada Higijenskog zavoda, 1931.). No moguć je i donekle suprotan postupak, naime uvlačenje građevine od ruba parcele i izvedba konkavnog pročelja (Juraj Denzler, kuća Mikuličić, 1925.; D. Ibler: Okružni ured za osiguranje radnika u Mostaru, 1930.), a primjera, kako izvedenih tako i onih u projektnim rješenjima, ima mnogo i nije ih potrebno dalje navoditi. Brojni su i drugi projekti koji zaobljenim oblicima odgovaraju na atipičan oblik parcele i zatečene ulične poteze, poput Weissmannove škole Grad u Splitu (1928.), Ehrlichove Privilegovane agrarne banke u Beogradu (1931.) i tolikih drugih.

Kakvo je u tom kontekstu značenje Zemljakova izbora zaobljene forme za osnovu dominirajućeg volumena njegove škole? Ponajprije, on nije bio potaknut bilo kakvim regulacijskim okvirom jer je škola podizana u dotad posve neizgradenom prostoru, a konveksni je trakt znatno odmaknut kako od Rapske tako i od Nove (Olipske) ulice. Arhitekt je u njega linijski smjestio učionice i utoliko predstavlja najvažniji dio školske zgrade. Nema razloga pretpostaviti da je konveksni oblik sadržavao bilo kakvu utilitarnu komponentu. Učionice bi bile u svakom slučaju dobro osvijetljene zahvaljujući južnom položaju i velikim prozorima; dakle i uobičajeno prizmatično oblikovanje trakta dalo bi u tom pogledu podjednak rezultat, ovako je kut upada svjetla u isto doba dana samo nešto drukčiji, što nije od funkcionalne važnosti. ${ }^{31} \mathrm{Kad}$ spominjemo osunčanost i svjetlo, uputit ćemo na zanimljivo rezoniranje zabilježeno u knjizi Problemi savremene arhitekture iz 1932. godine: maketa projekta za banovinsku bolnicu u Splitu, s potpisom Freudenreicha i Deutscha, pokazuje 

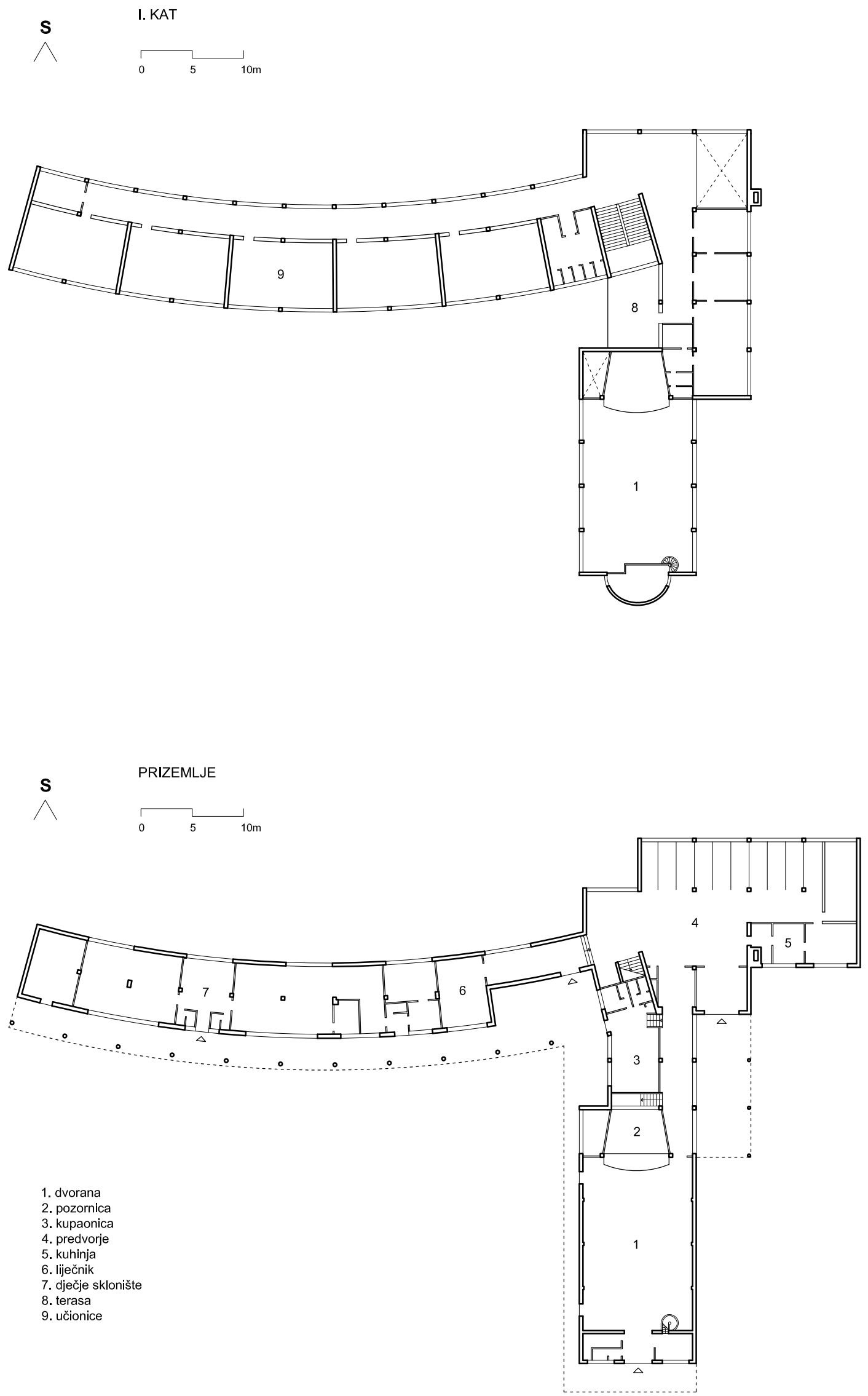

4. Tlocrti, projekt 1938. (Goran Vareško, prema: S. Limani - V. Žanko, Zagrebačke škole. Škole i fakulteti međuratnog razdoblja)

Floor plans, project from 1938 


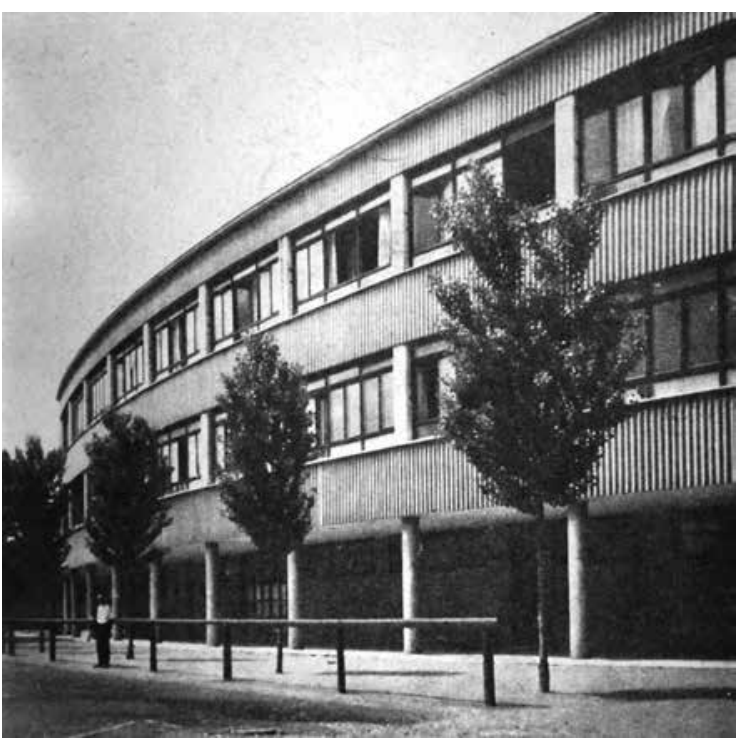

5. Glavni trakt, južno pročelje (Čovjek i prostor, 120, 1963.) Main tract, south façade

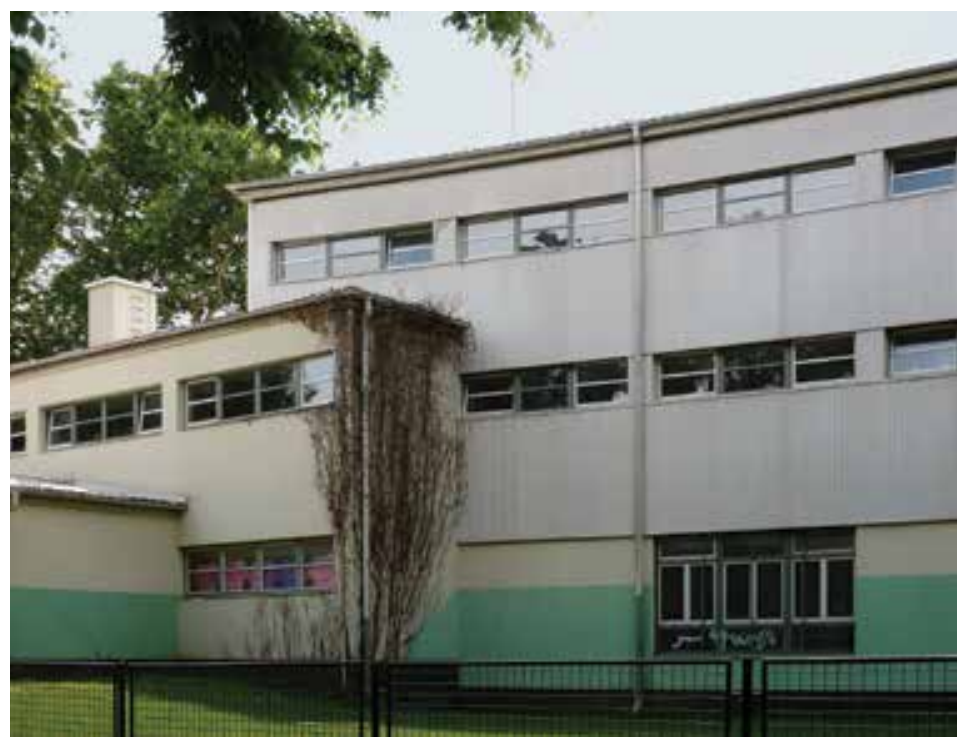

6. Sjeverno pročelje

North façade također trakt s glavnim konveksnim pročeljem prema jugu. Pritom je najvažnija legenda koja upućuje da je »oblik glavne zgrade analogan dnevnom putu sunca.$^{32} \mathrm{Bez}$ sumnje je dragocjena takva informacija koja valjda svjedoči o genezi autorske zamisli, no osim samog nadahnuća, to rješenje nije moglo imati funkcionalno značenje kako u slučaju bolnice, tako i u slučaju naše škole. Naime, da postoje evidentne koristi od takve dispozicije, bile bi brojne soliterne javne zgrade - pa i stambene zgrade - tako projektirane, što ipak nije slučaj. Je li Zemljak koncipirajući zgradu imao na umu dnevnu putanju Sunca, posve je spekulativna tema. Bliskija nam je zamisao da je uveo zaobljenu formu kako bi trakt, a onda i ukupnu kompoziciju, učinio zanimljivijom ili dinamičnijom.

\section{Prema zaključku}

Tlocrtna odnosno volumna kompozicija naše škole radikalno je asimetrična i time različita od većine Zemljakovih školskih zgrada, a posebno onih najistaknutijih. Arhitekt je ovdje prostorno razdvojio funkcije utoliko što je u jedno krilo smjestio učionice, a u drugo servisne funkcije i administraciju. No jasno je da asimetrija nije bila uvjetom za razdvajanje funkcija jer se to može provesti i u simetričnom rasporedu, kako to pokazuje njegova škola u Koturaškoj, ali i rani projekt za Sigečicu. Drugi svoj asimetričan koncept ostvario je odmah nakon Rapske školom na Knežiji: oblikovno posve različite, one imaju ipak srodan funkcijski raspored tako što je jedno krilo učioničko, drugo je administrativno i završava dvoranom, a u njihovu je spoju stubište. Volumna kompozicija škole na Knežiji pritom - uzmemo li u obzir i pripojeno obdanište - teži obuhvaćanju, zatvaranju, a škola u Rapskoj je u prostoru rastvorena kompozicija. Imamo li na umu cijeli raspon Zemljakovih školskih zgrada, od one na Novoj cesti (1928.) do škole u Strmoj ulici (1957.), pokazat će se znatne stilske, ali i kvalitativne razlike. Najuspjelije zgrade potječu dakako iz najproduktivnijih tridesetih godina i tu je škola Rapska jedna od jednostavnijih, što ne znači i manje zanimljivih. No jedinstvena je pojavom onoga čime Zemljak - s izuzetkom stubišnih volumena u Selskoj - nije uopće operirao: zaobljenom formom, i to kao osnovom najvećeg volumena zgrade.

Taj postupak pokazuje da je bio inovativan, pa i sklon eksperimentu. Isto se pokazalo i u njegovu tretiranju pročelja ove škole. Oblogu pročelja glavnog trakta riješio je valovitim salonitom, kako smo to vidjeli u idejnom projektu. $U$ dosadašnjoj literaturi uloga valovitog materijala tumačena je kao dinamizacija pročelja, odnosno kao podcrtavanje već dinamiziranoga konveksnog trakta. Međutim, ponudit ćemo nešto drukčije shvaćanje tog rješenja: ono se optički vrlo dobro nadovezuje na rustiku sljemenskog kamena koju je arhitekt bio zamislio za prizemlje glavnog pročelja. Pravilno neravnu površinu valovitog salonita doživjeli smo kao određenu »industrijaliziranu rustiku«, a ona se i svojom sivom bojom i sjenama približava kamenu prirodne rustike. Zemljakova temeljna zamisao vidi se u rečenom nacrtu, gdje se tamno tijelo glavnog trakta jasno odvaja od bijelo ožbukanoga poprečnog sklopa. Pritom treba zamijetiti da bi u modernoj arhitektonskoj tradiciji očekivano bilo rustiku pronaći na razvedenom $\mathrm{i}$ »usitnjenom « istočnom, servisnom sklopu volumena, a glatko izvedena pročelja na čisto koncipiranom velikom tijelu, no u Zemljakovu je rješenju upravo obratno.

Podjednako tako je ne posve uobičajena kombinacija rustike glavnog trakta i ravnog krova. U tipičnim rješenjima, 
pa i u Zemljakovim ostvarenjima, rustika je korištena u kombinaciji s kosim krovom, ${ }^{33}$ nastavljajući na zasadama tradicionalne regionalne arhitekture. Ravan krov je pak jedan od glavnih principa ili uporišta tzv. internacionalnog stila u modernoj arhitekturi i tek se postupno i iznimno pojavio i u sintetičkim ostvarenjima zajedno s elementima tradicionalne arhitekture. Takva su rješenja međutim u pravilu bila povezana s manjim zadatcima poput obiteljskih kuća (Weissmannova vila Kraus, 1937.), a malokad za javne građevine većeg mjerila. ${ }^{34}$ Stoga je glavni trakt Zemljakove

\section{Bilješke}

1 Ivan Zemljak (1893. - 1963.) studirao je u Grazu i Pragu. Radio je kod Viktora Kovačića, a od 1921. do 1930. zaposlen je na mjestu referenta u građevnom odjelu zagrebačkoga Gradskog poglavarstva. Kao voditelj Odsjeka za novogradnje istoga poglavarstva (1930. - 1939.) osobito je bio zauzet izgradnjom škola prema suvremenim pedagoškim načelima, i to posebno ondje gdje su nedostajale, na zagrebačkoj periferiji. Osim projektima za niz školskih zgrada i dječjih skloništa, Zemljak je djelovao i pišući u stručnoj periodici, predstavljajući svoja ostvarenja.

U tridesetim godinama izgrađena je glavnina Zemljakovih zgrada namijenjenih obrazovanju i odgoju, ujedno i najkvalitetnija njegova ostvarenja na tom planu: osnovna škola, Jordanovac 108, 1930.; dječje sklonište, Trakošćanska 45, 1930.; osnovna škola i obdanište, Selska 95, 1930; osnovna škola, Jakićeva 23, 1933.; osnovna škola, Koturaška 75, 1935.; dječje sklonište, Jordanovac 106, 1935.; dječje sklonište, Laščinska 17, 1935.; obrtna škola, Savska 39, 1937.; osnovna škola, Rapska 3, 1938.; osnovna škola i obdanište, Ljubljanska 33, 1939.

Uz autore navedene na drugim mjestima ovog rada, o Zemljaku su pisali i: VLADO ANTOLIĆ, Uz škole i obdaništa arhitekta Ive Zemljaka, Arhitektura, 5 (1952.), 31-35; ANDRO VID MIHIČIĆ, Ivan Zemljak, Čovjek i prostor, 120 (1963.), 4-5; NEVEN MIKAC, Hommage arhitektu Ivanu Zemljaku 1893-1963, Čovjek i prostor, 1 (1983.), 20-22; TOMISLAV PREMERL, Hrvatska moderna arhitektura izmedu dva rata. Nova tradicija, Zagreb, 1989., 62, 63, 84-86; DARJA RADOVIĆ MAHEČIĆ, Moderna arhitektura u Hrvatskoj 1930-ih, Zagreb, 2007., 111-118; TAMARA BJAŽIĆ KLARIN, "Za novi, ljepši Zagreb«. Arhitektonski i urbanistički natječaji međuratnog Zagreba, Zagreb, 2020., 29, 61, 210.

2

Među malobrojne radove koji barem ukratko analiziraju zgradu pripadaju: IVO MAROEVIĆ, Život i djelo arhitekta Ive Zemljaka, Iz starog i novog Zagreba, 5 (1974.), 229-253, te vrijedna publikacija SILVIJA LIMANI - VANJA ŽANKO, Zagrebačke škole. Škole i fakulteti međuratnog razdoblja, Zagreb, 2007., 4, 7-20, 31, 32.

\section{3}

Odgovarajući dojam za školu na Jordanovcu Ivo Maroević opisao je osebujnom formulacijom »malo suviše gorda«, IVO MAROEVIĆ (bilj. 2), 236.

4

Raskošan kod ove škole nije samo njezin raspored i obuhvat, niti samo složeno oblikovanje njezinih bočnih tijela, nego i to da je Zemljaku pošlo za rukom da u nekim učionicama postigne obostrano dnevno osvjetljenje, duž dvaju nasuprotnih zidova. škole, kako ga vidimo u projektu, i shvatimo li obradu njegova pročelja kao naročiti vid rustike, zanimljiva sinteza dviju načelno različitih arhitektonskih tendencija. Školska zgrada u Rapskoj, pomalo zaboravljena među svojim znamenitijim srodnicama, pokazuje ipak svoje specifične vrijednosti, koje je svakako čine jedinstvenom kreacijom među njima.

Nakon potresa 22. ožujka 2020. škola je dobila zelenu ozna$k u$, uz preporuke: »1. sanirati dilatacijske reške; 2 . sanirati pregradne zidove; važno: prekontrolirati dimnjak «. ${ }^{35}$
5

"...koji po tretmanu volumena, arhitektonskom izrazu u cjelini i detalju predstavlja možda i najveći domet Zemljakova stvaranja...«: ZDENKO KOLACIO, Arhitekt Ivan Zemljak, Arhitektura, 5-6 (1962.), 4; »...ta je zgrada potpuno izbalansirana i znači datum u našoj suvremenoj arhitekturi«: IVO MAROEVIĆ (bilj. 2), 242. 6

ALEKSANDER LASLO, Ivan Zemljak i Zagreb, Čovjek i prostor, 16 (1993.), 16. U popisu Zemljakovih radova izostala je škola na Novoj cesti.

7

IVAN ZEMLJAK, Uz nove zagrebačke škole, Arhitektura, 12 (1933.), 188, 189.

8

»Ne bi se moglo danas reći, da saradnja između pedagoga i arhitekta, koja bi se morala nužno očekivati, zadovoljava. Nedostaje volje za uzajamno pobuđivanje i dopunu u radu. Nove pedagoške misli morale bi doći do jačeg izražaja«; isto, 190. Također: LUJO THALLER, O gradnji škola, Arhitektura, 12 (1933.), 204-206.

9

Zemljak je 1939. ovako pisao o skloništima: »Među skrbi za omladinu spada i ustanova dječjih skloništa (obdaništa, asili infantili, écoles maternelles, nursery infant schools, Kindergärten). (...) U skloništa se primaju sada samo djeca siromašnih roditelja koji su preko dana na radu. Primanje se vrši na osnovu molbe i pregleda kućnih i drugih prilika. Djeca primaju u skloništu hranu, besplatno, uz naplatu ili uz pola cijene, prema imovnom stanju roditelja«; IVAN ZEMLJAK, Nova dječja skloništa u Zagrebu, Voda i plin, 2 (1939.), 59, 61.

10

TAMARA BJAŽIĆ KLARIN, Ernest Weissmann. Društveno angažirana arhitektura, 1926.-1939., Zagreb, 2015., 60.

11

IVAN ZEMLJAK (bilj. 7), 185.

12

Današnja je Sigečica omeđena ulicama Držićevom, Ulicom grada Vukovara, Radničkom te Slavonskom avenijom.

13

Pozornost zaslužuje činjenica da je posrijedi rani primjer projekta »paviljonske škole « i u sklopu ukupne hrvatske moderne arhitekture. Raniji je, primjerice, Antolićev projekt škole za Varaždin (1930.), o kojemu Premerl piše: »To je osnovna škola 
u zelenilu, otvorena i vedra, škola zasnovana prema novim pedagoškim gledanjima za oblikovanje školskih zgrada koja su kod nas tada tek krčila sebi put «, TOMISLAV PREMERL (bilj. 1), 86. Međutim, Antolićevo grupiranje učionica u paviljone i njihov češljast poredak bio je vrlo nalik prethodnoj Reformschule kraj Frankfurta (E. May i A. Loecher, 1929.), te je odmah u nas bio prepoznat kao očit utjecaj. O školama na otvorenom vidjeti MIA ROTH-ČERINA, Utjecaj pokreta za odgoj u prirodi na razvoj paviljonske škole. Odabrani europski i hrvatski primjeri iz 30-ih godina 20. stoljeća, Prostor, 41 (2011.), 60-73, posebno 66-68.

\section{4}

Teško je kazati je li štednja uzrokovala odustajanje od prvotnog koncepta jer smo vidjeli da i tijekom tridesetih, pa i nakon rata nastaju ostvarenja češljastog rasporeda učionica.

\section{5}

Državni arhiv u Zagrebu (dalje: DAZG), Zbirka građevne dokumentacije (dalje: ZGD), Rapska 3.

16

IVO MAROEVIĆ (bilj. 2), 240.

\section{7}

DAZG, Gradsko poglavarstvo Zagreb, Građevni odjel, 203.

\section{8}

Ovom ćemo prilikom spomenuti samo najvažnije preinake učinjene naknadno, kojima je stvoreno stanje što ga zatječemo danas: umjesto dvorane prema jugu, podignuta je dvorana (dakako prema tuđem projektu) sa sjeverne strane škole. $\mathrm{Na}$ južnoj je strani pak produljen jednokatan trakt sa zbornicom, na mjestu izvorno zamišljene dvorane. U prizemlju glavnog trakta, na istočnoj strani, dograđen je zid u ravnini pročelja te preuređen izlaz na dvorište; nije pritom dovoljno dokumentirano kako to da se rustika javlja na tom naknadno podignutom zidu. U cijelom je prizemlju osim toga, kako na pročelju, tako i na začelju, izmijenjen prvotni format prozora. U recentnim obnovama uklonjen je izvorni valoviti salonit na glavnom traktu i zamijenjen valovitim limom, uza začelje istog trakta dograđeno je vanjsko stubište, a svi su dijelovi škole natkriveni plitkim kosim krovom.

\section{9}

Zanimljivo je tu primijetiti da se u nacrtu istočnog pročelja očito potkrala pogreška jer glavni trakt, čiji se dio ovdje vidi kao najviši volumen, nije prikazan sivo, nego bijelo.

20

DAZG, ZGD, Rapska 3.

21

Sačuvan je tlocrt sa po šest učionica, na kojemu je naknadno ucrtana redukcija za po jednu učionicu; DAZG, ZGD, Rapska 3.

22

U ono doba zakonski propisana odvojenost ženske i muške djece mogla se provesti dvama podjednakim krilima, kao u Selskoj, ili se, kao u Rapskoj, nastava odvijala u dvije smjene: prijepodne dječaci, poslijepodne djevojčice; DAZG, Državna mješovita pučka škola u Rapskoj ulici (dalje: DR), knj. 1, 10.

23

IVAN ZEMLJAK (bilj. 7), 186.

24

Uistinu je riječ o dvama paralelnim tankim zidovima između kojih je slobodan prostor. U tehničkom opisu zgrade Zemljak je naveo: »zidovi od opeke $12 \mathrm{~cm}$ sa zračnim prostorom« (v. bilj. 28).

25

Podsjetimo da je dvorana u jordanovačkoj školi pokraj tih imala i treću funkciju, da posluži i kao kapela.

26

U zahtjevu za izdavanje građevinske dozvole od 5. 5. 1938. naznačen je razlog za odustajanje od dvorane: »Napominje se, da se dvorana gombaonice zajedno sa skloništem od napadaja iz zraka, koje se predviđa ispod gombaonice, za sada ne može izvoditi zbog nedostatka novčanih sredstava. «; DAZG, ZGD, Rapska 3. Može se nagađati da je ista situacija uzrokovala i skraćivanje glavnog trakta za duljinu jedne učionice.

27

Iz zapisnika sjednice nastavničkog vijeća 1. 4. 1940.: »G. upravitelj škole moli nastavnike da vode strogu kontrolu o čistoći šk. djece i da 'prljavce' šalju na pranje u šk. zgradi. Ipak, nemaju nastavnici prava siliti učenike da idu na skupno školsko kupanje«; DAZG, DR, knj. 1, 8.

Dodajmo - možda uljepšanu - ocjenu što ju je ostavio gradski školski nadzornik Štivić, obišavši novu školu 29. i 31. 5. te 22. 6. 1940.: "Iako ovu školu polaze većinom periferijska sirotinjska djeca, postignut je vrlo lijep uspjeh. Radi se skoro u svim razredima po metodi aktivne škole«; DAZG, DR, knj. 1, 11a.

28

DAZG, ZGD, Rapska 3.

29

IVO MAROEVIĆ (bilj. 2), 240.

30

»Nedefiniranost je najočitija u unutrašnjosti prizemlja gdje autor nije dovoljno istaknuo potrebnu reprezentativnost ulaznih prostora (Selska cesta i Jordanovac) «, IVO MAROEVIĆ, Arhitektura Ive Zemljaka, Život umjetnosti, 9 (1969.), 79.

31

Navedimo usput i to da zbog smještaja u konveksnom traktu učionice nemaju pravokutan tlocrtni oblik, nego su im dulje stranice dakako zaobljene, a kraće nisu paralelne. To se opaža tek pomnim promatranjem te ne predstavlja teškoću za uobičajeno funkcioniranje škole.

32

Problemi savremene arhitekture (ur. Stjepan Planić), Zagreb, 1932., 47.

33

Primjeri su dječje sklonište u Laščinskoj i škola na Knežiji, s kosim krovovima širokih streha, te zidovima u rustično tretiranoj opeci.

34

Takav jedan primjer može biti Weissmannov projekt za Đački oporavilišni dom, 1937.; glavni trakt ima vrlo blago nagnut jednovodni krov.

35

Zahvaljujemo na suradnji prilikom pripreme ovoga rada Mihaeli Barbarić (Državni arhiv u Zagrebu), Diani Dujmović (OŠ Rapska), Sonji Gaćina Škalamera (Hrvatski školski muzej), dr. sc. Nini Gazivodi (Gradski zavod za zaštitu spomenika kulture i prirode), Ivani Knezović (Dječji vrtić Vladimira Nazora), Silviji Limani (Muzej Brdovec) te dr. sc. Heli Vukadin-Doronjga (Muzej grada Zagreba). 


\section{Summary}

\section{Andrej Žmegač \\ "Fragment of a Circular Cornice with Protrusion to the South": Architect Ivan Zemljak's School in Rapska Street}

The primary school building in Rapska Street in Zagreb is one of the lesser-known works of Ivan Zemljak, the most prominent Croatian architect of school buildings. His earlier schools were conceived under the influence of Dutch neoplasticism, shaped symmetrically and executed with pure volumes of white plastered façades. The school in Rapska introduced some novelties, such as a radically asymmetrical composition and especially the rounded form, which is an exception in Zemljak's oeuvre. The rounded, convex shape was given to the main tract of the school, which is a floor higher than the rest of the building and houses the classrooms. The conceptual design from 1938 shows that he imagined it in a dark colour, different from the transversely placed, white plastered administrative tract. The grey of the main tract was to be achieved with rustic stone and corrugated cement slabs on the rest of the façade; this coating of vertical surfaces with slabs that were usually used for roofing was the architect's innovation for this school.

The school was built on the then outskirts of Zagreb and was attended mostly by poor working-class children. In those days, new schools were actually intended to serve as social institutions and therefore had a kitchen, a bathroom, and a doctor's office; and the school in Rapska Street was no exception. The children were also taken care of after school, because their parents often worked from morning until evening. This was done in the so-called shelters (later kindergartens) for preschool as well as school children. Such a shelter was also included in the main tract of the school in Rapska, on the ground floor.

Keywords: modern architecture, primary school, outskirts, Ivan Zemljak, Zagreb 